\title{
Determination Essential and Toxic Metals in Bitter, Milk and White Chocolate Samples from Eight Different Manufacturers
}

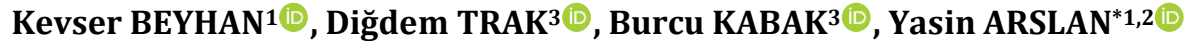 \\ ${ }^{1}$ Burdur Mehmet Akif Ersoy University, Faculty of Arts and Science, Nanoscience and Nanotechnology \\ Department, 15100, Burdur, Turkey \\ ${ }^{2}$ Karabük University, Faculty of Science, Chemistry Department, 78050, Karabük, Turkey \\ ${ }^{3}$ Burdur Mehmet Akif Ersoy University, Faculty of Arts and Science, Chemistry Department, 15100, Burdur, \\ Turkey
}

(Alınış / Received: **.**.20**, Kabul / Accepted: **.**.20**, Online Yayınlanma / Published Online: **.**.20**)

\section{Keywords}

Bitter chocolate,

Milk chocolate,

White chocolate,

Essential metal,

Toxic metal

\begin{abstract}
Chocolate is consumed by people of all ages in every part of society. Chocolate is a very rich source of many essential metals for the body but it also may involve toxic metals. Therefore, the accurate and precise method should be selected and applied to determine the essential and toxic metals in the chocolate samples. In present study, $\mathrm{Na}, \mathrm{K}, \mathrm{Mg}$ (II), $\mathrm{Ca}(\mathrm{II}), \mathrm{Cu}(\mathrm{II}), \mathrm{Fe}(\mathrm{III}), \mathrm{Zn}(\mathrm{II}), \mathrm{Cd}(\mathrm{II}), \mathrm{Cr}(\mathrm{III})$, $\mathrm{Pb}(\mathrm{II})$ and $\mathrm{Ni}(\mathrm{II})$ metals were determined by using flame atomic absorption spectrometry (FAAS) in 24 different chocolate samples of 3 different types including 8 different brands of bitter, milk and white. The microwave-assisted digestion system was also used for the chocolate samples digestions. All results were given at $95 \%$ of confidence level. In addition, the accuracy of the method was also investigated by the analysis of a standard reference material (spinach leaves, NIST-1570a).
\end{abstract}

\section{Sekiz Farklı Üreticiden Temin Edilen Siyah, Sütlü ve Beyaz Çikolata Örneklerindeki Gerekli ve Zehirli Metallerin Tayini}

\section{Anahtar Kelimeler}

Siyah çikolata, Sütlü çikolata, Beyaz çikolata, Esansiyel metal, Zehirli metal

\begin{abstract}
Özet: Çikolata, toplumun her kesiminden her yaștan insan tarafından tüketilen bir besindir. Çikolata, vücut için gerekli metaller için zengin bir kaynaktır, ancak içeriğinde toksik metaller de bulunabilmektedir. $\mathrm{Bu}$ yüzden çikolata örneklerindeki gerekli ve toksik metalleri belirlemek için doğru ve kesin yöntem seçilmelidir. Bu çalışmada 8 farklı markanın siyah, sütlü ve beyaz olmak üzere 3 farklı tipteki toplam 24 farklı çikolata örneğinde $\mathrm{Na}, \mathrm{K}, \mathrm{Mg}$ (II), Ca (II), Cu (II), Fe (III), Zn (II), Cd (II), Cr (III), Pb (II) ve Ni(II) tayinleri alevli atomik absorpsiyon spektrometre (FAAS) kullanılarak gerçekleştirilmiştir. Çikolata numunelerinin çözünürleştirilmesi için ise mikrodalga çözme sistemi kullanılmıştır. Çalış̧mada tüm sonuçlar \% 95 güven seviyesinde verilmiștir. Ek olarak, yöntemin doğruluğu ıspanak yaprağı standart referans maddesinin (NIST-1570a) analizi ile test edilmiştir.
\end{abstract}

\section{Introduction}

Chocolate is produced by cocoa beans obtained from cocao tree (Theobroma cacao). It is one of the foods widely consumed by people of various ages around the world as it is found in various foods such as ice cream, cake and biscuit [1].

There are three main types of chocolate such as, bitter, milk and white depending on the milk, sugar, cocoa bean, cocoa butter and condiment materials [2]. Among these types, bitter chocolate has the least amount of added fat and the largest cocoa mass. Milk and white chocolates contain high amounts of cocoa butter and milk. While these two types generally have similar components, white chocolate does not contain cocoa mass [3].

The properties and definitions of cocoa and chocolate products are specified in the EC Directive 2000/36 [4]. Despite its high sugar and fat content, chocolate also contains vitamins, carbohydrates, polyphenols and minerals, such as calcium, copper and iron etc. [5]. For example, it is known that dark chocolate 
contains at least 56 elements. While potassium, magnesium, calcium and phosphorus are the most abundant macro elements, iron is also the most abundant micro element. Furthermore, these elements (macro and micro) play an important role in the proper functioning of living organisms [6]. In addition, it is known that heavy metal contents in chocolate samples are also increased towards high concentrations due to the heavy metal content of cocoa [4]. Therefore, it is necessary to determine the metal content in chocolate samples.

Nowadays, many different analytical techniques are used to determine the metal content of food samples, such as flame atomic absorption spectrometry [7], graphite furnace atomic absorption spectrometry [8], cold vapour atomic absorption spectrometry [9], inductively coupled plasma optical emission spectrometry [10], inductively coupled plasma mass spectrometry [11] and X-Ray fluorescence spectroscopy [12]. Among these techniques, FAAS is the preferred techniques in metal determinations due to its advantages, such as simplicity, speed, accurate and precision measurement [13]. Before the analysis, it is an important issue in the digestion of food products with high organic matter content, such as chocolate. Microwave digestion is a fast and reliable method that can be used in the digestion of such foods [14].

In this study, the metal contents of bitter, milk and white chocolate samples were determined. For this, the chocolate samples were digested by microwave digestion system and $\mathrm{Na}, \mathrm{K}, \mathrm{Mg}$ (II), $\mathrm{Ca}$ (II), $\mathrm{Cu}$ (II), Fe (III), Zn (II), Cd (II), Cr (III), Pb (II) ve Ni(II) were determined by FAAS. Three different measurements were made to determine the concentration of the elements in the chocolate samples and the results were given at $95 \%$ of confidence level. The accuracy of the method was verified by the experiment performed on the standard reference material (spinach leaves, NIST-1570a).

\section{Material and Method}

\subsection{Apparatus}

The determination of all studied metals in this study were carried out using a flame atomic absorption spectrometer (ATI Unicam 939 model) and the operating conditions in the determination step were given in Table 1.

The microwave digestion system (CEM, Mars 6 $240 / 50$ model) was used to digest the chocolate samples and standard reference material. The digestion process for all samples was as follows: 15 $\mathrm{min} /$ heating, $15 \mathrm{~min} /$ thawing $\left(200^{\circ} \mathrm{C}\right), \quad 15$ $\min /$ cooling.
Table 1. Operation conditions for metal determination

\begin{tabular}{cccc}
\hline Metals & $\begin{array}{c}\text { Wavelenght } \\
\text { (nm) }\end{array}$ & $\begin{array}{c}\text { Slit width } \\
\text { (nm) }\end{array}$ & $\begin{array}{c}\text { Lamb current } \\
\text { (mA) }\end{array}$ \\
\hline $\mathrm{Ca}$ & 422.7 & 0.5 & 6.0 \\
$\mathrm{Mg}$ & 285.2 & 0.5 & 4.0 \\
$\mathrm{Cu}$ & 324.8 & 0.5 & 5.0 \\
$\mathrm{Fe}$ & 248.3 & 0.2 & 15.0 \\
$\mathrm{Zn}$ & 213.9 & 0.5 & 10.0 \\
$\mathrm{Cd}$ & 228.8 & 0.5 & 8.0 \\
$\mathrm{Cr}$ & 357.9 & 0.5 & 12.0 \\
$\mathrm{~Pb}$ & 217.0 & 0.5 & 10.0 \\
$\mathrm{Ni}$ & 232 & 0.2 & 15.0 \\
\hline
\end{tabular}

*Na and $\mathrm{K}$ measurement were performed in emission mode of FAAS.

\subsection{Reagents}

All solutions were prepared with analytical reagent grade. The resistivity of $18.2 \mathrm{M} \Omega \cdot \mathrm{cm}$ of ultra-pure water was obtained by PURIS, Expe-up water purification system. The concentrated $\mathrm{HNO}_{3}$ and $\mathrm{H}_{2} \mathrm{O}_{2}$ solutions were purchased from Merck. The stock aqueous solution (1000 mg/L) of $\mathrm{Na}, \mathrm{K}, \mathrm{Mg}, \mathrm{Ca}, \mathrm{Cu}$, $\mathrm{Fe}, \mathrm{Zn}, \mathrm{Cd}, \mathrm{Cr}, \mathrm{Pb}$ and $\mathrm{Ni}$ were prepared by dissolving their salts, such as $\mathrm{NaCI}$ (Sigma-Aldrich), $\mathrm{KNO}_{3}$ (Merck), $\quad \mathrm{Mg}\left(\mathrm{NO}_{3}\right)_{2} \cdot 6 \mathrm{H}_{2} \mathrm{O}$ (Riedel-de Haën), $\mathrm{CaCI}_{2} \cdot 2 \mathrm{H}_{2} \mathrm{O}$ (Sigma-Aldrich), $\mathrm{CuSO}_{4} \cdot 5 \mathrm{H}_{2} \mathrm{O}$ (SigmaAldrich), $\mathrm{FeCI}_{3} \cdot 6 \mathrm{H}_{2} \mathrm{O}$ (Merck), $\mathrm{ZnCI}_{2}$ (Merck), $\mathrm{Cd}\left(\mathrm{NO}_{3}\right)_{2} \cdot 4 \mathrm{H} 2 \mathrm{O}$ (Aldrich), $\mathrm{Cr}\left(\mathrm{NO}_{3}\right)_{3} \cdot 9 \mathrm{H}_{2} \mathrm{O}$ (Merck), $\mathrm{Pb}\left(\mathrm{NO}_{3}\right)_{2}$ (Merck) and $\mathrm{Ni}\left(\mathrm{NO}_{3}\right)_{2} \cdot 6 \mathrm{H}_{2} \mathrm{O}$ (Merck), respectively.

\subsection{Collection and preparation of chocolate samples}

A total of 24 chocolate samples from 8 different brands of bitter, milk and white chocolate varieties were purchased from Burdur city markets at Turkey and websites.

During the digestion of the chocolate samples, about $1.0 \mathrm{~g}$ of chocolate samples was firstly placed in teflon vessels and $5 \mathrm{~mL}$ of concentrated $\mathrm{HNO}_{3}$ and $3 \mathrm{~mL}$ of concentrated $\mathrm{H}_{2} \mathrm{O}_{2}$ were added in the vessels. In the experimental studies, the determination of $\mathrm{Cu}$ (II), $\mathrm{Cd}(\mathrm{II}), \mathrm{Cr}(\mathrm{III}), \mathrm{Pb}(\mathrm{II})$, and $\mathrm{Ni}(\mathrm{II})$, which were found in trace levels in chocolate samples, were directly performed in FAAS without any dilution. However, for the determination of $\mathrm{Na}, \mathrm{K}, \mathrm{Mg}(\mathrm{II}), \mathrm{Ca}(\mathrm{II}), \mathrm{Zn}$ (II), and $\mathrm{Fe}(\mathrm{II})$ metals, the necessary dilution processes (5-250 fold) based on metals were carried out to enter their concentrations in the linear range of calibration graphs. Afterwards, their concentrations found in the calibration graphs were multiplied by dilution factors based on metals to find their exact concentrations.

In addition to this, $0.0732 \mathrm{~g}$ of standard reference material (spinach leaves, NIST-1570a) was digested with $10 \mathrm{~mL}$ of concentrated $\mathrm{HNO}_{3}$ using the digestion procedure described in Section 2.1. 


\section{Results and Discussion}

In this study, the concentrations of $\mathrm{Na}, \mathrm{K}, \mathrm{Mg}$ (II), $\mathrm{Ca}(\mathrm{II}), \mathrm{Cu}(\mathrm{II}), \mathrm{Fe}(\mathrm{III}), \mathrm{Zn}(\mathrm{II}), \mathrm{Cd}(\mathrm{II}), \mathrm{Cr}(\mathrm{III}), \mathrm{Pb}(\mathrm{II})$ and $\mathrm{Ni}(\mathrm{II})$ in the chocolate samples after digestion procedure were determined by FAAS. The standard solutions were prepared between 0.5 and $10 \mathrm{mg} / \mathrm{L}$ depending on metals and the linear equations of calibration graphs were obtained by using the absorbance and intensity values of standard solutions as shown in Table 2. The concentrations of metals in the chocolate samples were calculated by these linear equations depending on metals.

Table 2. Linear equations obtained from calibration graphs

\begin{tabular}{clc}
\hline Metals & \multicolumn{1}{c}{ Lineer equation } & $\mathbf{R}^{\mathbf{2}}$ \\
\hline $\mathrm{Na}$ & $\mathrm{y}=5.6718 \mathrm{x}+4.6974$ & 0.993 \\
$\mathrm{~K}$ & $\mathrm{y}=3,498 \mathrm{x}+1.7449$ & 0.997 \\
$\mathrm{Ca}$ & $\mathrm{y}=0.0138 \mathrm{x}+0.0015$ & 0.999 \\
$\mathrm{Mg}$ & $\mathrm{y}=0.0317 \mathrm{x}+0.0129$ & 0.999 \\
$\mathrm{Cu}$ & $\mathrm{y}=0.0357 \mathrm{x}+0.0027$ & 0.996 \\
$\mathrm{Fe}$ & $\mathrm{y}=0.0182 \mathrm{x}+0.0067$ & 0.998 \\
$\mathrm{Zn}$ & $\mathrm{y}=0.109 \mathrm{x}+0.0015$ & 0.994 \\
$\mathrm{Cd}$ & $\mathrm{y}=0.061 \mathrm{x}+0.008$ & 0.999 \\
$\mathrm{Cr}$ & $\mathrm{y}=0.012 \mathrm{x}+0.006$ & 0.990 \\
$\mathrm{~Pb}$ & $\mathrm{y}=0.036 \mathrm{x}-0.004$ & 0.999 \\
$\mathrm{Ni}$ & $\mathrm{y}=0.0193 \mathrm{x}-0.0004$ & 1.000 \\
\hline
\end{tabular}

\section{1. $\mathrm{Na}$ and $\mathrm{K}$ amounts in the chocolate samples}

Sodium (Na) and potassium (K) are both considered essential mineral nutrients [15]. The amounts of $\mathrm{Na}$ in the chocolate samples were shown in Table 3. In this study, the concentration of $\mathrm{Na}$ was found to be the lowest in a bitter chocolate sample marked with 5 whose concentration was $429 \pm 7 \mathrm{mg} / \mathrm{kg}$, whereas concentration in white chocolate sample marked with 8 was found to be the highest with the value of $3936 \pm 281 \mathrm{mg} / \mathrm{kg}$.

Table 3. Amount of $\mathrm{Na}$ in the chocolate samples, $\bar{x} \pm \frac{t s}{\sqrt{N}}$, $\mathrm{N}: 3$

\begin{tabular}{clll}
\hline Brand & Bitter & $\begin{array}{l}\text { Chocolate } \\
\text { type milk }\end{array}$ & White \\
\hline 1 & $2166 \pm 47$ & $2749 \pm 50$ & $3477 \pm 50$ \\
2 & $638 \pm 14$ & $3131 \pm 129$ & $3271 \pm 76$ \\
3 & $496 \pm 10$ & $2158 \pm 75$ & $3811 \pm 82$ \\
4 & $647 \pm 25$ & $2927 \pm 47$ & $3070 \pm 57$ \\
5 & $429 \pm 7.0$ & $3440 \pm 25$ & $3228 \pm 80$ \\
6 & $440 \pm 40$ & $2290 \pm 278$ & $2393 \pm 62$ \\
7 & $1087 \pm 12$ & $3237 \pm 97$ & $2833 \pm 72$ \\
8 & $697 \pm 14$ & $2624 \pm 50$ & $3936 \pm 281$ \\
\hline
\end{tabular}

The amounts of $\mathrm{K}$ in the chocolate samples were given in Table 4 . While the concentration of $\mathrm{K}$ was found to be the lowest in a milk chocolate sample marked with 2 whose concentration was $5331 \pm 87$ $\mathrm{mg} / \mathrm{kg}$, that of $\mathrm{K}$ was found to be the highest with the value of $17972 \pm 57 \mathrm{mg} / \mathrm{kg}$ in a bitter chocolate sample marked with 1 .
Table 4. Amount of $\mathrm{K}$ in the chocolate samples, $\bar{x} \pm \frac{t s}{\sqrt{N}}, \mathrm{~N}: 3$

\begin{tabular}{clll}
\hline Brand & \multicolumn{1}{c}{ Bitter } & $\begin{array}{l}\text { Chocolate } \\
\text { type milk }\end{array}$ & White \\
\hline 1 & $17972 \pm 57$ & $6892 \pm 336$ & $6101 \pm 80$ \\
2 & $6502 \pm 85$ & $5331 \pm 87$ & $6003 \pm 430$ \\
3 & $12315 \pm 55$ & $6142 \pm 72$ & $6245 \pm 80$ \\
4 & $17381 \pm 258$ & $7779 \pm 80$ & $8849 \pm 85$ \\
5 & $11411 \pm 67$ & $9094 \pm 70$ & $6832 \pm 119$ \\
6 & $10571 \pm 147$ & $7430 \pm 72$ & $7337 \pm 70$ \\
7 & $6084 \pm 169$ & $8530 \pm 42$ & $8477 \pm 70$ \\
8 & $8903 \pm 94$ & $7322 \pm 122$ & $9025 \pm 70$ \\
\hline
\end{tabular}

3.2. $\mathrm{Mg}$ (II) and $\mathrm{Ca}$ (II) amounts in the chocolate samples

Magnesium (Mg) is an essential metal for the body that acts as a cofactor of more than 300 enzymatic reactions. It was reported that some diseases, such as hypertension, diabetes, osteoporosis, glucose intolerance and myocardial infarction may be associated with magnesium deficiency [16]. The amounts of $\mathrm{Mg}(\mathrm{II})$ in the chocolate samples were shown in Table 5 . The content of $\mathrm{Mg}$ (II) was in a range of between $291 \pm 20$ and $4805 \pm 249 \mathrm{mg} / \mathrm{kg}$, where the lowest concentration was found in a white chocolate sample marked with 2 , and the highest concentration was found in bitter chocolate marked with 6 .

Table 5. Amount of $\mathrm{Mg}(\mathrm{II})$ in the chocolate samples, $\bar{x} \pm$ $\frac{t s}{\sqrt{N}}, \mathrm{~N}: 3$

\begin{tabular}{clll}
\hline Brand & Bitter & $\begin{array}{l}\text { Chocolate } \\
\text { type milk }\end{array}$ & White \\
\hline 1 & $3276 \pm 42$ & $665 \pm 86$ & $408 \pm 42$ \\
2 & $1831 \pm 75$ & $436 \pm 42$ & $291 \pm 20$ \\
3 & $2178 \pm 87$ & $704 \pm 112$ & $1256 \pm 117$ \\
4 & $1618 \pm 221$ & $2090 \pm 159$ & $546 \pm 50$ \\
5 & $4363 \pm 250$ & $1319 \pm 70$ & $840 \pm 82$ \\
6 & $4805 \pm 249$ & $800 \pm 124$ & $544 \pm 59$ \\
7 & $1836 \pm 124$ & $1198 \pm 122$ & $458 \pm 97$ \\
8 & $4542 \pm 234$ & $947 \pm 85$ & $636 \pm 70$ \\
\hline
\end{tabular}

Calcium (Ca) is another essential mineral which is the most abundant in the body. Ca is essential for growth and bone density, also keeps the heart pumping, muscles moving and nerves in communication [17]. The amounts of $\mathrm{Ca}$ (II) in the chocolate samples were given in Table 6 . The amounts of $\mathrm{Ca}$ (II) were in a range of between $995 \pm 77$ and $35436 \pm 880 \mathrm{mg} / \mathrm{kg}$, where the lowest concentration was found in a bitter chocolate sample marked with 6 , and the highest concentration was found in white chocolate marked with 5 .

\subsection{Cu(II) amount in the chocolate samples}

Determination of the copper $(\mathrm{Cu})$ in the chocolate samples is an important issue for its compounds because they are widely used as fungicides in cocoa 
cultivation. In addition, $\mathrm{Cu}$ plays a role in a variety of biological activities in the body and it is necessary for a strong immune system. For this reason, it is important to determine the amount of it in the chocolate samples for nutritional adequacy [18]. The amounts of $\mathrm{Cu}(\mathrm{II})$ in the chocolate samples were given in Table 7. The content of $\mathrm{Cu}$ was determined in only bitter chocolates. The concentration of $\mathrm{Cu}$ was in a range of between $6.9 \pm 1.0 \mathrm{mg} / \mathrm{kg}$ (brand 2) and $15.8 \pm 0.7 \mathrm{mg} / \mathrm{kg}$ (brand 4).

Table 6. Amount of $\mathrm{Ca}(\mathrm{II})$ in chocolate samples, $\bar{x} \pm \frac{t s}{\sqrt{N}}$, $\mathrm{N}: 3$

\begin{tabular}{clll}
\hline Brand & Bitter & $\begin{array}{c}\text { Chocolate } \\
\text { type milk }\end{array}$ & White \\
\hline 1 & $4090 \pm 191$ & $4351 \pm 186$ & $4165 \pm 291$ \\
2 & $1236 \pm 34$ & $1951 \pm 37$ & $4127 \pm 395$ \\
3 & $1293 \pm 142$ & $5745 \pm 283$ & $6856 \pm 270$ \\
4 & $1398 \pm 57$ & $5831 \pm 263$ & $4175 \pm 286$ \\
5 & $1675 \pm 40$ & $7933 \pm 184$ & $35436 \pm 880$ \\
6 & $995 \pm 77$ & $5034 \pm 375$ & $7135 \pm 288$ \\
7 & $1870 \pm 57$ & $7457 \pm 181$ & $5660 \pm 181$ \\
8 & $1051 \pm 70$ & $5816 \pm 286$ & $6855 \pm 201$ \\
\hline
\end{tabular}

Table 7. Amount of $\mathrm{Cu}$ in chocolate samples, $\bar{x} \pm \frac{t s}{\sqrt{N}}$, N:3

\begin{tabular}{clll}
\hline Brand & Bitter & $\begin{array}{l}\text { Chocolate } \\
\text { type milk }\end{array}$ & White \\
\hline 1 & $14.4 \pm 0.6$ & N.D. & N.D. \\
2 & $6.9 \pm 1.0$ & N.D. & N.D. \\
3 & $9.1 \pm 1.0$ & N.D. & N.D. \\
4 & $15.8 \pm 0.7$ & N.D. & N.D. \\
5 & $11.8 \pm 0.7$ & N.D. & N.D. \\
6 & $15.6 \pm 0.5$ & N.D. & N.D. \\
7 & $7.30 \pm 0.7$ & N.D. & N.D. \\
8 & $9.4 \pm 1.5$ & N.D. & N.D. \\
\hline
\end{tabular}

aN.D.= Not detected

\subsection{Fe(III) amount in the chocolate samples}

Iron (Fe) is one of the major trace metals and its deficiency causes anaemia. On the other hand, excess amount Fe intake in the body may be associated with important ailments, such as heart disease, liver disease and cancer [19]. The amounts of Fe(III) in the chocolate samples were shown in Table 8. The concentration of Fe was in a range of between N.D. (not detected) and $363 \pm 50 \mathrm{mg} / \mathrm{kg}$, where the highest concentration was found in bitter chocolate marked with 5 .

Table 8. Amount of Fe in chocolate sample, $\bar{x} \pm \frac{t s}{\sqrt{N}}, \mathrm{~N}: 3$

\begin{tabular}{clll}
\hline Brand & Bitter & $\begin{array}{l}\text { Chocolate } \\
\text { type milk }\end{array}$ & White \\
\hline 1 & $8.9 \pm 1.0$ & $24.7 \pm 0.5$ & N.D. $^{\mathrm{a}}$ \\
2 & $67.9 \pm 7.0$ & $20.5 \pm 1.5$ & $7.6 \pm 1.2$ \\
3 & $222 \pm 10$ & $85.4 \pm 3.0$ & $21.3 \pm 1.0$ \\
4 & $83.7 \pm 7.5$ & $47.1 \pm 5.0$ & $18.5 \pm 1.5$ \\
5 & $363 \pm 50$ & $81 \pm 7.0$ & $14.1 \pm 1.0$ \\
6 & $89 \pm 6.0$ & $14.8 \pm 2.0$ & $7.9 \pm 1.5$ \\
7 & $114 \pm 22$ & $32.6 \pm 1.0$ & $10.6 \pm 2.0$ \\
8 & $128 \pm 4.0$ & $32.3 \pm 1.0$ & N.D. \\
\hline
\end{tabular}

$\mathrm{aN} . \mathrm{D} .=$ Not detected

\subsection{Zn(II) amount in the chocolate samples}

Zinc ( $\mathrm{Zn}$ ) is an important trace element which is involved in many biochemical events in the biological systems. Its deficiency can cause some diseases, such as eye and skin lesions, diarrhea, impaired wound healing and growth retardation [20]. In this study, the concentration of $\mathrm{Zn}$ was in a range of between $4.6 \pm 0.2$ and $65 \pm 1.0 \mathrm{mg} / \mathrm{kg}$, where the lowest concentration was found in a white chocolate sample marked with 2 , and the highest concentration was found in bitter chocolate marked with 6 . The amounts of $\mathrm{Zn}(\mathrm{II})$ in the chocolate samples were given in Table 9.

Table 9. Amount of $\mathrm{Zn}$ in the chocolate samples, $\bar{x} \pm \frac{t s}{\sqrt{N}}$, $\mathrm{N}: 3$

\begin{tabular}{clll}
\hline Brand & Bitter & $\begin{array}{c}\text { Chocolate } \\
\text { type milk }\end{array}$ & White \\
\hline 1 & $39 \pm 1.5$ & $10 \pm 0.2$ & $8.5 \pm 0.2$ \\
2 & $46 \pm 1.5$ & $11 \pm 1.5$ & $4.6 \pm 0.2$ \\
3 & $29.7 \pm 0.5$ & $9.5 \pm 0.7$ & $12.4 \pm 0.5$ \\
4 & $57 \pm 1.5$ & $37 \pm 2.5$ & $8.9 \pm 1.2$ \\
5 & $44 \pm 1.2$ & $25 \pm 1.5$ & $11 \pm 0.2$ \\
6 & $65 \pm 1.0$ & $61 \pm 2.0$ & $10 \pm 0.2$ \\
7 & $45 \pm 3.5$ & $33 \pm 2.0$ & $11 \pm 0.7$ \\
8 & $35 \pm 1.5$ & $30 \pm 2.5$ & $12 \pm 0.5$ \\
\hline
\end{tabular}

\section{6. $\mathrm{Cd}(\mathrm{II}), \mathrm{Cr}$ (III), $\mathrm{Pb}$ (II) and $\mathrm{Ni(II)}$ amounts in the chocolate samples}

Cadmium (Cd) is another dangerous metal even at trace levels and it was reported that exposure of it can cause liver damage or kidney failure [21].

Chromium III (Cr(III)) is an essential micronutrient for the body. It has a beneficial effect on the metabolism of carbohydrates, lipids and certain proteins, and increases to insulin activity in diabetic patients [22].

The presence of lead $(\mathrm{Pb})$ in cocoa and its derivatives has been investigated for many years. $\mathrm{Pb}$ is harmful to the human body even at trace level. Calcium metabolism may be affected after $\mathrm{Pb}$ enters the human body. It can cause abdominal and headache, hypertension, central nervous system disorder, and kidney dysfunction [21].

Nickel (Ni) amount in the chocolate samples has been determined by researchers in the different studies. The chocolate samples can be contaminated during the chocolate production process with Ni. Moreover, cocoa butter is another essential ingredient that may contain high concentrations of $\mathrm{Ni}$. While trace amounts of $\mathrm{Ni}$ act as an activator of some enzymes, it may cause bronchial bleeding and accumulate in the lungs at high levels of $\mathrm{Ni}$ [23].

In this study, the amounts of $\mathrm{Cd}(\mathrm{II}), \mathrm{Cr}$ (III), $\mathrm{Pb}(\mathrm{II})$ and $\mathrm{Ni}(\mathrm{II})$ in all chocolate samples were not detected 
because the amounts of these metals were lower than the value of LOD for FAAS detection.

\subsection{Validation of method}

The accuracy of the method was evaluated to determine Manganese (Mn) in a certified reference material (spinach leaves, NIST-1570a). The accuracy of the method was calculated from three replicate measurements at 95\% confidence level. The Mn value was found to be $68.9 \pm 4.0 \mathrm{mg} / \mathrm{kg}$ (recovery: 91\%), which was in good agreement with certified value $(75.9 \pm 1.9 \mathrm{mg} / \mathrm{kg})$, in which relative error was found to be $-9 \%$.

\section{Discussion and Conclusion}

In this study, the amounts of $\mathrm{Na}, \mathrm{K}, \mathrm{Mg}(\mathrm{II}), \mathrm{Ca}(\mathrm{II})$, $\mathrm{Cu}(\mathrm{II}), \mathrm{Fe}(\mathrm{III}), \mathrm{Zn}(\mathrm{II}), \mathrm{Cd}(\mathrm{II}), \mathrm{Cr}(\mathrm{III}), \mathrm{Pb}(\mathrm{II})$ and $\mathrm{Ni}(\mathrm{II})$ in three different types of chocolates (bitter, milk and white) purchased from 8 different producers were investigated. Based on experimental results, the investigated chocolate samples can be considered as a good source of essential metals. Because, essential metals, which are $\mathrm{Na}, \mathrm{K}, \mathrm{Mg}(\mathrm{II}), \mathrm{Ca}(\mathrm{II}), \mathrm{Cu}(\mathrm{II}), \mathrm{Fe}(\mathrm{III})$, $\mathrm{Zn}$ (II) in the chocolate samples might significantly contribute to healthy nutrition. In addition, it was found that bitter chocolate was especially richer for essential metals. The differences between the results may be due to the contents of the different brands of chocolate samples which were not used in the same proportions during the production. Furthermore, some comparisons were performed for the maximum allowable limits of metals in chocolates and/or their raw materials with obtained results in this study. For example, according to the European Legislation, the maximum tolerable levels for $\mathrm{Pb}$ (II) and $\mathrm{Cd}(\mathrm{II})$ in cocoa powder should be $1 \mathrm{mg} / \mathrm{kg}$ and $0.3 \mathrm{mg} / \mathrm{kg}$, respectively [4]. In our study, $\mathrm{Pb}$ (II) and $\mathrm{Cd}(\mathrm{II})$ amounts in the investigated chocolate samples do not have a hazardous effect because the amount of them was lower than the value of LOD for FAAS detection. Secondly, it has been stated that the average content of $\mathrm{Ni}$ in chocolate types can be $3.8 \mathrm{mg} / \mathrm{kg}$ in the literature [24]. In our study, Ni(II) amounts were also lower than the value of LOD for FAAS detection.

Table 10. Comparison of investigated metals with literature data

\begin{tabular}{|c|c|c|c|c|}
\hline \multirow{2}{*}{ Metals, mg/kg } & \multicolumn{3}{|c|}{ Other studies } & \multirow{2}{*}{ This study } \\
\hline & Bitter & Milk & White & \\
\hline $\mathrm{Na}$ & $\begin{array}{l}45.6-270[5] \\
43-5590[25] \\
45-435[26]\end{array}$ & $\begin{array}{l}484-1095[5] \\
634-1281[26]\end{array}$ & $728-5001[5]$ & $\begin{array}{l}429-2166(\mathrm{~B})^{\mathrm{a}} \\
2158-3440(\mathrm{M})^{\mathrm{b}} \\
2393-3936(\mathrm{~W})^{\mathrm{c}}\end{array}$ \\
\hline $\mathrm{K}$ & $\begin{array}{l}4885-8574[5] \\
4950-12700[25]\end{array}$ & $4379-6546[5]$ & $3555-7442[5]$ & $\begin{array}{l}6084-17972(\mathrm{~B}) \\
5331-9094(\mathrm{M}) \\
6003-9025(\mathrm{~W})\end{array}$ \\
\hline $\mathrm{Mg}$ & $\begin{array}{l}1083-2775[5] \\
855-1610[25] \\
1104-1457[26]\end{array}$ & $\begin{array}{l}580-821[5] \\
460-693[26]\end{array}$ & $147-265$ [5] & $\begin{array}{l}1618-4805(\mathrm{~B}) \\
436-2090(\mathrm{M}) \\
291-1256(\mathrm{~W})\end{array}$ \\
\hline $\mathrm{Ca}$ & $\begin{array}{l}653-903[5] \\
118-919[25] \\
449-1421[26] \\
\end{array}$ & $\begin{array}{l}1584-2449 \\
1422-2447\end{array}$ & $2056-2467$ [5] & $\begin{array}{l}995-4090(\mathrm{~B}) \\
1951-7933(\mathrm{M}) \\
4127-35436(\mathrm{~W})\end{array}$ \\
\hline $\mathrm{Cu}$ & $\begin{array}{l}7.6-19.5[5] \\
9.5-17.7[25] \\
8.51-15.05[26] \\
1.4-4.4[18]\end{array}$ & $\begin{array}{l}3.0-5.4[5] \\
3.09-6.10[26] \\
1.7-4.2[18]\end{array}$ & $<0.16$ [5] & $\begin{array}{l}6.9-15.8(B) \\
\text { dN.D. (M) } \\
\text { N.D. }(W)\end{array}$ \\
\hline $\mathrm{Fe}$ & $\begin{array}{l}57-227[5] \\
47-211[25] \\
86.6-150[26] \\
15-51[18] \\
\end{array}$ & $\begin{array}{l}20-62.7[5] \\
20.1-88.1[26] \\
3-60[18]\end{array}$ & $<1.6-7.9$ [5] & $\begin{array}{l}8.9-363(B) \\
14.8-85.4(M) \\
\text { N.D.-21.3 (W) }\end{array}$ \\
\hline $\mathrm{Zn}$ & $\begin{array}{l}14-33[5] \\
16.3-28.9[25] \\
18.5-25.9[26] \\
3.2-19[18]\end{array}$ & $\begin{array}{l}8.40-13.4[5] \\
9.11-17.0[26] \\
4-27[18]\end{array}$ & $4.8-6.8[5]$ & $\begin{array}{l}29.7-65(\mathrm{~B}) \\
9.5-61(\mathrm{M}) \\
4.6-12.4(\mathrm{~W})\end{array}$ \\
\hline $\mathrm{Cd}$ & $\begin{array}{l}0.007-0.040[4] \\
0.022-0.242[25] \\
0.02-0.19[18] \\
\end{array}$ & $0.01-0.14[18]$ & - & $\begin{array}{l}\text { N.D. (B) } \\
\text { N.D. (M) } \\
\text { N.D. (W) }\end{array}$ \\
\hline $\mathrm{Cr}$ & $\begin{array}{l}<0.6-2.8[5] \\
0.23-1.69[25]\end{array}$ & $<0.6[5]$ & $<0.6[5]$ & $\begin{array}{l}\text { N.D. (B) } \\
\text { N.D. (M) } \\
\text { N.D. (W) }\end{array}$ \\
\hline $\mathrm{Pb}$ & $\begin{array}{l}0.019-0.895[4] \\
0.25-0.86[25] \\
0.06-1.4[18] \\
\end{array}$ & $0.029-0.25$ [18] & - & $\begin{array}{l}\text { N.D. (B) } \\
\text { N.D. (M) } \\
\text { N.D. (W) }\end{array}$ \\
\hline $\mathrm{Ni}$ & $\begin{array}{l}5.0-10.2[5] \\
1.90-5.90[25] \\
0.2-5[18] \\
\end{array}$ & $\begin{array}{l}3.2-5.1[5] \\
0.2-2[18]\end{array}$ & $3.6-9.6[5]$ & $\begin{array}{l}\text { N.D. (B) } \\
\text { N.D. (M) } \\
\text { N.D. (W) }\end{array}$ \\
\hline
\end{tabular}

aB: Bitter chocolate, bM: Milk chocolate, $\mathrm{cW}$ : White chocolate, dN.D.: Not detected. 
Furthermore, according to Turkish Food Codex (TFC), the maximum allowable $\mathrm{Fe}, \mathrm{Zn}$ and $\mathrm{Cu}$ values in food samples were indicated as $0.2-25 \mathrm{mg} / \mathrm{kg}, 2-50 \mathrm{mg} / \mathrm{kg}$ and $15 \mathrm{mg} / \mathrm{kg}$, respectively [14]. While the obtained amount of $\mathrm{Fe}$ in our study was higher than the literature values, that of $\mathrm{Zn}$ and $\mathrm{Cu}$ were in good agreement with the literature values. Finally, the obtained results were compared with other studies in the literature and results were given in Table 10.

\section{Acknowledgment}

This study was based on a research supported by The Scientific and Technological Research Council of Turkey (TÜBITAK/BİDEP 2209A Project Number: 1919B011700910).

\section{Declaration of Ethical Code}

In this study, we undertake that all the rules required to be followed within the scope of the "Higher Education Institutions Scientific Research and Publication Ethics Directive" are complied with, and that none of the actions stated under the heading "Actions Against Scientific Research and Publication Ethics" are not carried out.

\section{References}

[1] Barreto, J. A., Assis, R. S. Cassella, R. J., Lemos, V. A. 2019. A Novel Strategy Based on In-Syringe Dispersive Liquid-Liquid Microextraction for The Determination of Nickel in Chocolate Samples. Talanta, 193, 23-28.

[2] Altunay, N., Elik, A., Gürkan, R. 2019. Vortex Assisted-Ionic Liquid Based Dispersive Liquid Liquid Microextraction of Low Levels of Nickel and Cobalt in Chocolate-Based Samples and Their Determination by FAAS. Microchemical Journal, 147, 277-285.

[3] Villa, J. E. L., Pereira, C. D., Cadore, S. 2015. A Novel, Rapid and Simple Acid Extraction for Multielemental Determination in Chocolate Bars. Microchemical Journal, 121, 199-204.

[4] Dico, G. M. L., Galvano, F., Dugo, G., D'ascenzi, C., Macaluso, A., Vella, A., Giangrosso, G., Cammilleri, G., Ferrantelli, V. 2018. Toxic Metal Levels in Cocoa Powder and Chocolate by ICPMS Method After Microwave-Assisted Digestion. Food Chemistry, 245 1163-1168.

[5] Oliveira, L. B., de Melo, J. C., Morte, E. S. B., de Jesus, R. M., Teixeira, L. S. G., Korn, M. G. A. 2021. Multi-Element Determination in Chocolate Bars by Microwave-Induced Plasma Optical Emission Spectrometry. Food Chemistry, 351, 129285.

[6] Kruszewski, B., Obiedziński, M. W. 2018. Multivariate Analysis of Essential Elements in Raw Cocoa and Processed Chocolate Mass Materials from Three Different Manufacturers.
LWT - Food Science and Technology, 98, 113123.

[7] Ercan, M. S. F., Ayylldız, M. F., Chormey, D. S. Bakırdere, S. 2021. Determination of Copper in Traditional Coffee Pot Water Samples by Flame Atomic Absorption Spectrometry and Matrix Matching Calibration Strategy After Switchable Solvent Based Liquid-Phase Microextraction. Environmental Monitoring and Assessment, 193, 5.

[8] Chaikhan, P., Udnan, Y., Ampiah-Bonney, R. J. Chaiyasith, W. C. 2021. Air-Assisted Solvent Terminated Dispersive Liquid-Liquid Microextraction (AA-ST-DLLME) for The Determination of Lead in Water and Beverage Samples by Graphite Furnace Atomic Absorption Spectrometry. Microchemical Journal, 162, 105828.

[9] Lemos, V. A., dos Santos, L. O. 2014. A New Method for Preconcentration and Determination of Mercury in Fish, Shellfish and Saliva by Cold Vapour Atomic Absorption Spectrometry. Food Chemistry, 149, 203-207.

[10] Manan, W. N. A. A., Zulkurnain, N. 2021. Determination of Selected Heavy Metal Concentrations in Water Spinach (Ipomea aquatica). Materials Science Forum, 1025, 279283.

[11] Qin, J., Su, Z., Mao, Y., Liu, C., Qi, B., Fang, G., Wang, S. 2021. Carboxyl-Functionalized Hollow Polymer Microspheres for Detection of Trace Metal Elements in Complex Food Matrixes by ICP-MS Assisted with Solid-Phase Extraction. Ecotoxicology and Environmental Safety, 208, 111729.

[12] Almeida, J. S., Meira, L. A., Oliveira, M. S., Teixeira, L. S. G. 2021. Direct Multielement Determination of $\mathrm{Cd}, \mathrm{Pb}, \mathrm{Fe}$, and $\mathrm{Mn}$ in Ground Coffee Samples Using Energy Dispersive X-Rayfluorescence Spectrometry. X-Ray Spectrometry, 50, 2-8.

[13] Kabak, B. Trak, D. Kendüzler, E., Tomul, F., Arslan, Y. 2020. Separation and Preconcentration of Cobalt(II) From Water Samples with Amberlite CG-120 Resin. Iranian Journal of Chemistry and Chemical Engineering, 39(5), 181-189.

[14] Güldaș, M., Dağdelen, A. F., Biricik, G. F. 2008. Determination and Comparison of Some Trace Elements in Different Chocolate Types Produced in Turkey. Journal of Food, Agriculture \& Environment, 6 (3\&4), 90-94.

[15] Tanase, C. M., Griffin, P., Koski, K. G., Cooper, M. J., Cockell, K. A. 2011. Sodium and Potassium in Composite Food Samples from The Canadian Total Diet Study. Journal of Food Composition and Analysis, 24, 237-243. 
[16] Jodral-Segado, A. M., Navarro-Alarcon, M., de la Serrana, H. L., Lopez-Martınez, M. C. 2003. Magnesium and Calcium Contents in Foods from SE Spain: Influencing Factors and Estimation of Daily Dietary Intakes. The Science of the Total Environment, 312, 47-58.

[17] Afkhami, A., Madrakian, T., Abbasi-Tarighat, M. 2008. Simultaneous Determination of Calcium, Magnesium and Zinc in Different Foodstuffs and Pharmaceutical Samples with Continuous Wavelet Transforms. Food Chemistry, 109, 660669.

[18] Rehman, S., Husnain, S. M. 2012. Assessment of Trace Metal Contents in Chocolate Samples by Atomic Absorption Spectrometry. Journal of Trace Element Analysis, 1(1), 1-11.

[19] Kassem, M. A., Amin A. S. 2013. Spectrophotometric Determination of Iron in Environmental and Food Samples Using Solid Phase Extraction. Food Chemistry, 141(3), 19411946.

[20] Bilandžic', N., Sedak, M., Đokic', M., Varenina, I., Kolanovic', B. S., Božic', Đ., Brstilo, M., Šimić, B. 2014. Determination of Zinc Concentrations in Foods of Animal Origin, Fish and Shellfish from Croatia and Assessment of Their Contribution to Dietary Intake. Journal of Food Composition and Analysis, 35, 61-66.

[21] Villa, J. E. L., Peixoto, R. R. A., Cadore, S. 2014.
Cadmium and Lead in Chocolates Commercialized in Brazil. Journal of Agricultural and Food Chemistry, 62, 8759-8763.

[22] Hernandez, F., Jitaru, P., Cormant, F., Noël, L., Guérin, T. 2018. Development and Application of A Method for Cr(III) Determination in Dairy Products by HPLC-ICP-MS. Food Chemistry, 240, 183-188.

[23] Dahiya, S., Karpe, R., Hegde, A. G., Sharma, R. M. 2005. Lead, Cadmium and Nickel in Chocolate and Candies from Suburban Areas of Mumbai, India. Journal of Food Composition and Analysis, 18(6), 517-522.

[24] Vanderschueren, R., Montalvo, D., Ketelaere, B.D. Delcour, J.A., Smolders, E. 2019. The Elemental Composition of Chocolates Is Related to Cacao Content and Origin: A Multi-Element Fingerprinting Analysis of Single Origin Chocolates. Journal of Food Composition and Analysis, 83, 103277.

[25] Mrmošanin, J. M., Pavlović, A. N., Krstić, J. N., Mitić, S. S., Tošić, S. B., Stojković, M. B., Micić, R. J., Đorđević, M. S. 2018. Multielemental Quantification in Dark Chocolate by ICP OES. Journal of Food Composition and Analysis, 67, $163-171$.

[26] Sager, M. 2012. Chocolate and Cocoa Products as A Source of Essential Elements in Nutrition. Nutrition \& Food Science, 2(1), 1000123. 